\title{
The impact of FinTech start-ups on incumbent retail banks' share prices
}

\author{
Yinqiao Li, Renée Spigt and Laurens Swinkels ${ }^{*}$ (D)
}

\author{
* Correspondence: \\ Iswinkels@ese.eur.nl \\ Erasmus University Rotterdam, \\ Burgemeester Oudlaan, 50 \\ Rotterdam, The Netherlands
}

\begin{abstract}
Background: This study aims to clarify the role of FinTech digital banking start-ups in the financial industry. We examine the impact of the funding of such start-ups on the stock returns of 47 incumbent US retail banks for 2010 to 2016.

Methods: To capture the importance of FinTech start-ups, we use data on both the dollar-volume of funding and number of deals. We relate these to the stock returns with panel data regression methods.

Results: Our results indicate a positive relationship exists between the growth in FinTech funding or deals and the contemporaneous stock returns of incumbent retail banks.

Conclusions: Although these results suggest complementarity between FinTech and traditional banking, we note that our results at the banking industry level are not statistically significant, and that the coefficient signs for about one-third of the banks are negative, but not statistically significant. Since the FinTech industry is young and our sample period short, we cannot rule out that our findings are spurious.

Keywords: Banks, Digital banking, Finance, FinTech, Innovation, Retail banks, Startups, Stock returns, Venture capital, Technology
\end{abstract}

\section{Background}

From Uber to Airbnb, disruptions have transformed many industries. Until recently, the financial sector remained largely untouched. This changed with the breakthrough of FinTech firms, which are "companies that use technology for banking, payments, financial data analytics, capital markets and personal financial management" (Huang, 2015). In 2015, global FinTech investment grew by 75\%, exceeding the high 22 billion USD amount, and continues to rise (Dickerson et al., 2015). This growing number threatens incumbent retail banks as a new wave of digital banking start-ups has emerged.

Different scenarios describe FinTech's long-term impact. The first scenario is optimistic as regards the newcomers' survival, arguing that the start-ups will gobble up key parts of the franchise of traditional retail banks. This scenario is likely to lead to negative stock reactions for traditional US retail banks when the FinTech industry in the US is growing. The other scenarios are more skeptical, suggesting either that the digital banking start-ups will simply fail, or that the traditional banks are so powerful that they will acquire the newcomers through takeovers (Sorkin, 2016). These scenarios imply no stock reactions for traditional US retail banks when the FinTech industry in

(c) The Author(s). 2017 Open Access This article is distributed under the terms of the Creative Commons Attribution 4.0 International License (http://creativecommons.org/licenses/by/4.0/), which permits unrestricted use, distribution, and reproduction in any medium, provided you give appropriate credit to the original author(s) and the source, provide a link to the Creative Commons license, and indicate if changes were made. 
the US is growing. To investigate the role of digital banking start-ups in the financial industry, our research question is as follows:

What is the impact of FinTech digital banking start-ups' funding on the stock returns of incumbent US retail banks?

This research specifically focuses on digital banking start-ups since they offer the same type of services as retail banks: accepting consumer deposits, facilitating payments, and lending money (Chishti and Barberis, 2016). Their funding serves as an indicator of their potential values. This study uses stock returns to estimate the impact of this funding on the performance of traditional banks. If the returns react negatively, these entrants might disrupt the industry, while a positive effect might imply complementarity. To specify the research, we select the United States because it has the largest FinTech industry, as well as the highest number of FinTech adopters (Ernst and Young, 2014).

Because FinTech is a recent development, very little scientific research has been conducted yet. However, existing research mainly stresses start-ups' ability to disrupt industries (Chishti and Barberis, 2016; Dickerson et al., 2015). Kauffman et al. (2015) support this view by stating that current financial firms mainly depend on underlying technology innovations and not on their historical market position. This consequently forces traditional banks to enhance their service quality and reduce transaction costs, acting according to strategic necessity rather than competitive advantage (Goh and Kauffman, 2013). Jun and Yeo (2016), however, deemphasize competition and potential substitution by stressing the complementary effect of FinTech. The contradicting views on the future of FinTech and the largely descriptive research motivate us to reassess the role of digital banking start-ups in the traditional banking industry using a quantitative approach.

This paper proceeds as follows. The second section reviews the conceptual and empirical literature on disruptive innovation and FinTech-related studies. The third section presents the data used for the analyses, followed by a methodology description in the fourth section. The fifth section discusses the results two subsections that address the volume of funding and the number of deals. Finally, the final section presents the conclusion from this research as well as its limitations and future research recommendations.

\section{Theoretical framework}

As technology evolves, products, critical success factors, and industry characteristics change (Afuah and Utterback, 1997). This phenomenon has greatly affected the taxi and hotel industry, in which Uber and Airbnb have largely replaced the traditional services by offering decentralized online peer-to-peer platforms (Cannon and Summers, 2014). Since FinTech start-ups follow the same customer-centric approach by offering alternatives such as peer-to-peer lending (Lin et al., 2015; Wang et al., 2015a, b; Wang et al., 2015a, b; Yan et al., 2015), one might expect a shift in the banking industry as well. Researchers apply consumer theory to examine whether digital banking start-ups indeed negatively affect traditional retail banks. This theory states that a new service will act as a complement when utilized jointly with an old service and will serve as a substitute if it can replace the old service by satisfying the same needs (Aaker and Keller, 1990; Frank, 2009). Thus, the services digital banking start-ups offer would benefit the 
traditional retail banks in the former case and affect the incumbents' performance in the latter case (Kaul, 2012). It might also be possible to observe no effect when examining stock returns, which could indicate that the complementary and substitution effects offset each other. Other explanations are that the start-ups are simply too small, our measure does not capture FinTech's value well, or FinTech serves a new channel.

\section{Substitution effect and disruptive innovation}

FinTech start-ups offering successful substitutes for traditional services might disrupt the retail banking industry. Christensen (1997) coined the term "disruptive innovation," which involves entrants that successfully target overlooked segments. In the case of FinTech, these could be 'unbanked' and 'underbanked' segments such as small businesses and the small dollar-loan market that do not generate enough profit for the labor intensive traditional banking industry. According to this theory, start-ups eventually displace the incumbents. FinTech companies could potentially spark such a disruptive evolution due to their new alternatives that enhance the efficiency and quality of services (Ferrari, 2016).

Efficiency increases are mainly due to loan personalization and the disintermediation of processes by eliminating middlemen, which significantly lowers transaction costs for consumers (PwC, 2016; KPMG, 2016). New technologies such as the "blockchain" also enhance efficiency (Peters and Panayi, 2015; Wood and Buchanen, 2015). These innovations will benefit FinTech firms more as banks often rely on decades-old IT infrastructure (Laven and Bruggink, 2016). Moreover, banks are usually less likely to adopt new technologies quickly due to the regulatory environment (Hannan and McDowell, 1984).

The quality of financial services also increases as the entrants have alternative methods to assess risk beyond the single credit score that banks examine. For instance, companies such as Kabbage and OnDeck get their information from social-media reviews and companies' usage of logistics firms when assessing small business performance (The Economist, 2015a, b). Furthermore, Avant employs advanced machine-learning algorithms to underwrite consumers whose credit scores were affected by the financial crisis. FinTech also enables a more diverse, and thus more stable, credit landscape. This is mainly because the operations of internet-based firms are less geographically concentrated than those of incumbent banks are (The Economist, 2015a, b). Entrants are therefore able to attract the smaller risky enterprises that traditional retail banks would normally reject (Dunkley, 2015). Lastly, newcomers avoid the two major risks related to banking: mismatched maturities and leverage. In contrast to banks, FinTech firms simply match borrowers and savers directly instead of converting short-term deposits into long-term assets (The Economist, 2015a, b).

A concrete example of a FinTech company with a potential substitution effect is Lending Club. It is the world's largest online marketplace connecting borrowers and investors, transforming the banking system since its establishment to make credit more affordable and investing more rewarding. Lending Club's similarity to traditional banks is obvious: they both provide personal loans, business loans, and other financial services to their customers. However, besides it low-cost operation, Lending Club has a different business model than traditional banks do. This company, as most other FinTech firms, focuses on its lending platform to connect borrowers and investors, meaning that 
Lending Club does not absorb the risk that borrowers will not pay back their loans. Traditional banks need to take on these risks because they also convert short maturity savings into long maturity loans. Furthermore, Lending Club's major source of income is transaction fees rather than interest income, which constitutes the key income of traditional banks. Lastly, due to its different business model, Lending Club is less exposed to regulations compared to traditional banks.

\section{Complementary effect and collaborations}

On the other hand, one might argue that FinTech firms will complement the retail banking services. A plausible reason is that many incumbent banks have seen the significance of FinTech and tried to incorporate these start-ups or technologies into their businesses, either through joint partnerships, service outsourcing, venture capital funding, or acquisitions. For these banks, FinTechs seem to benefit them more than disrupt them (PwC, 2016). Moreover, collaborations between banks and FinTech start-ups also benefit small players. By cooperating with banks, FinTechs may get access to global payment systems and the banks' own customer base. This lowers the barriers of entry for FinTech firms to the financial sector and enables them to gain more trust from their customers (Juengerkes, 2016).

A real-world example from the FinTech industry with potential complementary effects is Wealthfront. It is considered one of the biggest investment management platforms and online financial advisors. Founded in 2011, Wealthfront raised \$130 million, including a $\$ 64$ million round closed in October 2014. Wealthfront's similarity to traditional banks is that they both manage assets and investments for their customers. However, traditional banks, such as private banks, usually serve high-net-worth individuals with high income and sizable assets, while Wealthfront also provides investment services for less wealthy people. Additionally, Wealthfront only charges customers assets fees, with no commission fees. The simple and transparent pricing even enables Wealthfront to become a strong rival of the traditional banking industry.

\section{No impact observed}

If there is no effect, then FinTechs might serve a new channel because these firms often attract clients that traditional banking services do not normally cover. For instance, risky small companies, consumers with a lacking credit history, or the smalldollar loan market (Demos, 2016; Hayashi, 2016). FinTech companies use technology to assess these borrowers' creditworthiness inexpensively - an advantage over traditional banks with many small stores in lower-income neighborhoods across the country (Hayashi, 2016).

Of course, existing banks may also acquire FinTech companies to gain access to new technology, which would make it more difficult to find a direct relationship between FinTech funding and incumbent retail bank stock returns. For example, Capital One, the tenth largest bank in the US in terms of total assets and market capitalization, acquired FinTech start-up Level Money in 2015. The start-up was a San Francisco-based digital banking technology firm, which described itself on their homepage as "the leader in helping the next generation spend with confidence, save more and achieve financial balance." The company is best known for its award-winning personal finance app, 
which provides a simple solution to analyze and budget customers' financial positions. With more than 800,000 downloads to date, the app connects to 250 US financial institutions and specifically targets Millennials.

After its acquisition by Capital One, the FinTech firm became part of Capital One's Digital Innovation Team, which enables Capital One to strengthen its capabilities in digital banking technologies. In a blog post, Level Money CEO Fuentes said the deal helps his company continue to evolve and grow, called Capital One, "much younger and nimbler than any other top bank," and said it is "on a mission to transform the way banking is done."

No effect could also imply that the start-ups are still too small compared to largeestablished banks because these incumbents deal in trillions instead of billions. Furthermore, incumbents benefit from their ability to create credit easily and from ingrained strengths, such as their current accounts, which allow clients to securely store their money and have permanent access to it. Since this part of finance is heavily regulated, this sector attracts few FinTechs as competitors (The Economist, 2015a, b). Finally, no effect could also result from the substitution and complementary effects offsetting each other.

\section{Hypothesis}

To answer the research question, we need to test whether FinTech start-ups have a significant effect on the retail banking industry. If this effect exists, then they should affect the estimated stock returns of incumbent banks (Benner, 2007). Liu and Miller (2014) and Sood and Tellis (2009) add that the prospect of disruptive pressures should depress the stock prices of established firms. Therefore, the stock returns of incumbent retail banks should encounter a negative effect when disruption is expected.

To examine the likelihood of innovative disruption, we require a reasonable proxy. Prior studies show that external funding events provide a relevant and credible measure to compare the future success of start-ups, as external financing is critical for growth and survival (Dean and Giglierano, 1990; Davila et al., 2003; Mina et al., 2013). Therefore, it is reasonable to assume a positive relationship between the FinTech start-up's value and the external funding it receives. Thus, we can use digital banking start-ups' funding to examine the null hypothesis:

Funding in the US FinTech digital banking industry has no contemporaneous effect on the stock returns of US incumbent banks.

We proxy funding by the volume of funding and the number of funding deals. The latter might signal additional information about the potential value of the start-ups because a large volume of funding does not necessarily imply a large number of investors. Therefore, we introduce the number of funding deals as another industry measurement.

In addition to our hypothesis that links FinTech funding to stock prices, it would be interesting to investigate relationships with other metrics. For example, the relation between FinTech funding and bank competition, bank risk-taking, and merger and acquisition activity among incumbent retail banks. Unfortunately, we do not have reasonable proxies available to statistically test such hypothesis. This would be a worthwhile endeavor for future research. 


\section{Models of expected returns}

We use a model that estimates the expected stock returns to test the hypotheses. Many studies use Sharpe's (1964) capital asset pricing model (CAPM). However, the empirical implementation of this model is sufficiently poor to deny its validity (Fama and French, 2004).

To better explain the average returns on stocks and bonds, Fama and French (1993) extended the CAPM model to use three factors for the stock market: an overall market factor capturing the excess return of the market portfolio, a factor related to firm size, and a factor for book-to-market equity values, leading to the following $\operatorname{model}^{2}$ (Davis et al., 2000):

$$
E\left(R_{i}\right)-R_{f}=b_{i}\left[E\left(R_{m}\right)-R_{f}\right]+s_{i} E(S M B)+h_{i} E(H M L)
$$

Here, $\mathrm{Ri}$ is the return on asset $\mathrm{i}, \mathrm{Rf}$ is the risk-free interest rate, and RM is the return on the value-weighted market portfolio.

$\mathrm{SMB}$ is the equal-weighted averages of the returns on the three small stock portfolios minus the three big stock portfolios. Similarly, HML is the average return on a portfolio of high book-to-market equity stocks minus the average return on a portfolio of low book-to-market equity stocks, constructed to be neutral with respect to size. Despite its high empirical validity in asset pricing, the three-factor model still has a theoretical shortcoming. The $S M B$ and $H M L$ explanatory returns are not variables that capture investors' concerns, but are "brute force constructs" instead (Fama and French, 2004). Furthermore, both the three-factor model and the CAPM suffer from the momentum effect, indicating that stocks that do well tend to continue to do well and vice versa (Jegadeesh and Titman, 1993).

As an extension of the three-factor model, Fama and French (2015) introduced a five-factor model, adding profitability and investment factors:

$$
\begin{aligned}
E\left(R_{i}\right)-R_{f}= & b_{i} R M R F+s_{i} E(S M B)+h_{i} E(H M L)+r_{i} E(R M W) \\
& +c_{i} E(C M A) .
\end{aligned}
$$

Here, $R i$ is the return on asset $i, R f$ is the risk-free interest rate, and $R M R F$ is the excess return on the value-weight market portfolio.

$R M W$ is the average return on the two robust operating profitability portfolios minus the average return on the two weak operating profitability portfolios. $R M W$ is the average return on the two conservative investment portfolios minus the average return on the two aggressive investment portfolios. This study uses both the FamaFrench three-factor model and five-factor model to capture the expected stock returns of the incumbent retail banks. Note that there is no general agreement on which asset pricing model best describes the cross-section of stock returns. By including both models, we partially address the robustness of our results for different specifications of the asset pricing model.

\section{Data}

This study used data from the venture finance-data firm CB Insights to identify US digital banking start-ups closely related to retail banks. CB Insights gathers data from different sources, such as regulatory filings (such as Form D), investor websites, 
company websites, and (social) media. In addition, some investors post data directly to $\mathrm{CB}$ Insights. ${ }^{3}$ Our analysis depends on public disclosure of FinTech deals to be captured in the CB Insights database. Note that it would also be difficult for investors in incumbent banks to change their view on the share price if FinTech deals remain private.

To retrieve the sample, we first applied several filters to companies that engage in FinTech activities and are closely related to retail banks. The main industries we selected included "Internet," "Mobile and Telecommunications," and "Financial," and refined them by selecting industries and subindustries. For "Internet," we filtered firms for "Internet Software and Services" with "Accounting and Finance" as the subindustry. For "Mobile and Telecommunications," we selected the "Mobile Software and Services" industry, with "Accounting and Finance" as the subindustry. Lastly, for "Financial," we applied "Asset/Financial Management," "Lending," "Payments," and "Retail Banking" as filters. This gave us a sample of 558 firms, which we narrowed down to 522 companies by excluding InsurTech. The selected FinTech start-ups are located in the US and received investments from January 2010 to March 2016. We chose this period because most FinTech firms began operating from 2010. CB Insights also provides the volume of funding ${ }^{4}$ committed to these start-ups and the number of deals since January 2010. Unfortunately, the start of FinTech coincides with the establishment of the Dodd-Frank Wall Street Reform and Consumer Protection Act that was signed into federal law on 21 July 2010. The major restructuring of financial regulation may have affected the share prices of traditional banks immediately at its introduction, in which case the effect on our results would be limited. However, a prolonged period in which investors needed to incorporate the new federal law fully into banks' share prices may influence our empirical results. However, it is not immediately clear how this would affect the month-to-month correlations of FinTech deals and bank prices.

The question may arise as to whether FinTech companies fall under similar regulations as traditional banks. On this point, regulators are somewhat ambivalent. On the one hand, they want to encourage innovation in the banking sector by lowering regulatory costs for start-ups. On the other hand, they are aware that for similar services, such as lending, they should have similar regulations in place to protect consumers and to create a level playing field with traditional banks. ${ }^{5}$ However, financial regulators are still deciding whether to introduce new and stricter regulation for FinTech companies, potentially weakening their threat to incumbent banks. ${ }^{6}$ Buchack et al. (2017) suggest that FinTech companies may be involved in regulatory arbitrage. Regulators may want to prevent this from keeping a grip on the financial system.

As Fig. 1 shows, funding volume is volatile month to month. We used the standardized values of the group mean and standard deviation. We also transformed the absolute amounts of funding into growth rates. The natural logarithm difference between month $t$ and month $t-1$ is a proxy for the growth rate of month $t$. We applied these transformations to the number of deals. Table 1 presents all transformations, and we show our raw data in Appendix Table 4 for reference. We also show the results for a subsample of only "Consumer FinTech" in Panel B, but we see that this subsample is rather small and is therefore less likely to fully capture the impact of FinTech on the retail banking industry. 


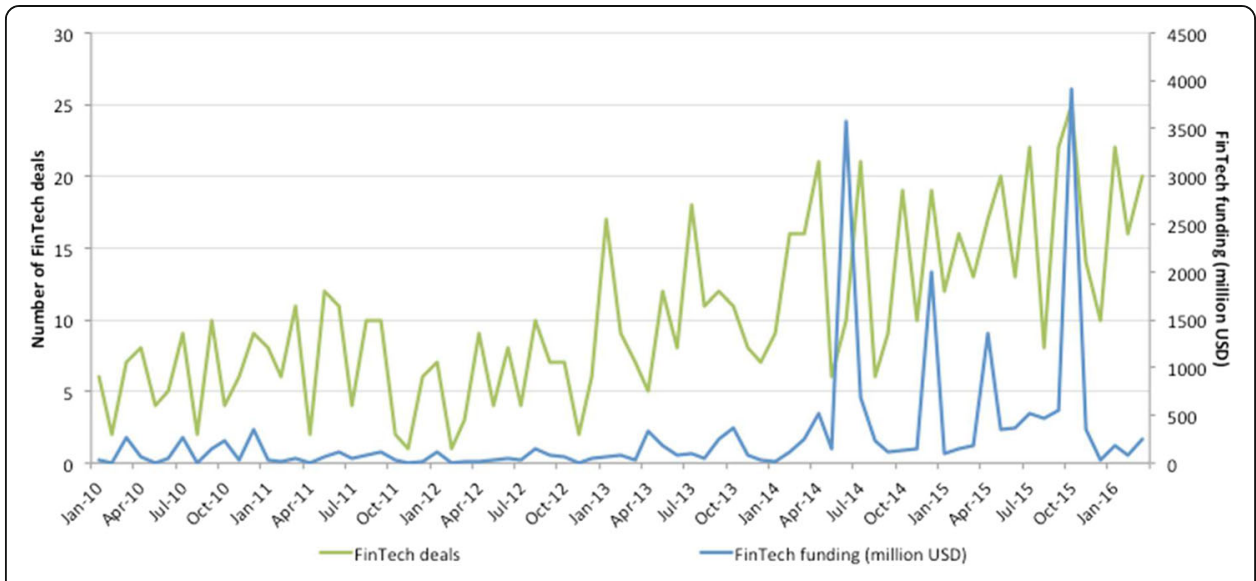

Fig. 1 Evolution of FinTech dollar-volume funding and number of FinTech deals

We retrieved a list of 138 US retail banks from Credio.com, a finance website that compares US financial services. ${ }^{7}$ We used the Bloomberg database to obtain banks' monthly total return indices. The total return index (TRI) is the dividend-adjusted stock price that measures both the capital gains and dividend distributions, assuming that dividends are reinvested in the same stock. We present the development of the total return indices of the financial sector and US market in Fig. $2{ }^{8}$

Of the 138 retail banks, we have total returns available for 47 banks. The excluded banks are often regional banks. We do not include non-listed banks because they would have only annual accounting returns such as Return-on-Equity (ROE) or Return-on-Assets (ROA) available. With annual data, it would be challenging to separate market-wide effects from the effects of FinTech funding. Hence, we include listed firms with monthly data to which we can link monthly FinTech funding data. Using performance information from non-listed banks could be a valuable extension for future research.

Since we do not have data available for the regional operations of traditional banks or FinTech companies, we cannot provide a more in-depth analysis of which FinTech deal flow affects which bank. This may be a fruitful area of further research. Note that the information we do have about the location of the headquarters may not be that helpful in this regard, as traditional banks have local offices to service clients. Moreover, the FinTech industry seems to be heavily concentrated in either the technology center in California, particularly Silicon Valley, or the financial center around New York, with the US industry concentrated in these locations with about 74,000 and 57,000 people employed in each location respectively (Ernst and Young, 2015). Accenture confirms that New York and Silicon Valley attract the most capital for the FinTech industry (Dickerson et al., 2015). Since FinTechs operate mainly digitally, office locations seem

Table 1 Data transformation

\begin{tabular}{lll}
\hline Original variable & Transformed variable & Formula \\
\hline FinTech funding volume & Standardized FinTech funding volume & $z_{t}=\frac{x_{t}-\bar{x}}{s}, t=1,2, \ldots, n$ \\
& FinTech volume growth rate & $g_{t}=\ln x_{t}-\ln x_{t-1}, t=2,3, \ldots, n$ \\
FinTech number of deals & Standardized FinTech number of deals & $z_{t}=\frac{x_{t}-\bar{x}}{s}, t=1,2, \ldots, n$ \\
& FinTech number of deals growth rate & $g_{t}=\ln x_{t}-\ln x_{t-1, t}=2,3, \ldots, n$ \\
\hline
\end{tabular}




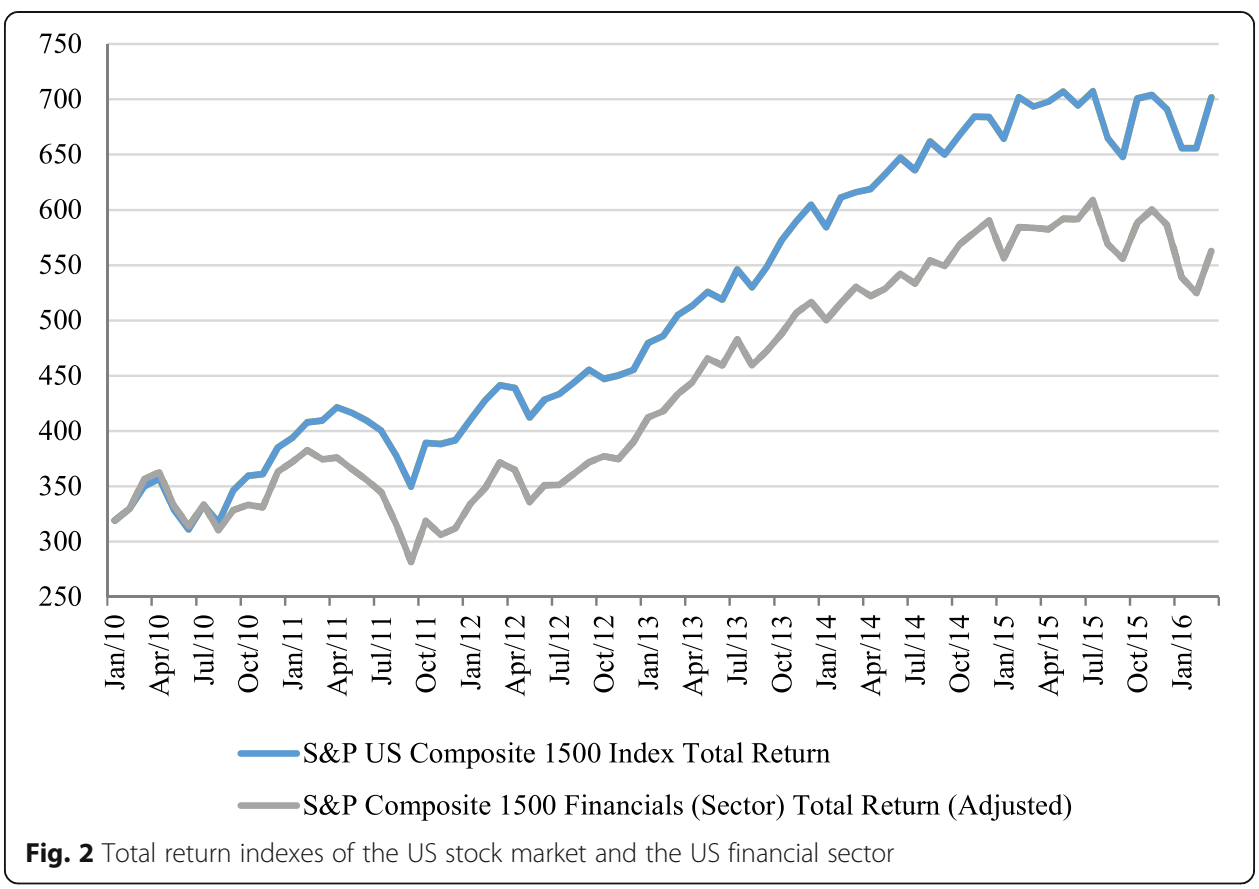

to be even less meaningful when trying to examine geographical relationships. However, since this study concentrates on the industry level, the sample is still representative and the aggregation of the 47 selected banks will nevertheless serve as a reasonable sample for the retail banking industry. Using banks' TRI, we calculate the stock return for month $\mathrm{t}$ as follows:

$$
R_{t}=\frac{T R I_{t}-T R I_{t-1}}{T R I_{t-1}}, t=2,3, \ldots, n
$$

To apply the Fama-French models, we retrieved the historical monthly values of the factors in Table 2 from Kenneth French's web page ${ }^{9}$ for January 2010 till March 2016.

\section{Methods}

We assume that the normal return for each incumbent retail bank is well-proxied by either the three-factor model (Fama and French, 1993) or the five-factor model (Fama

Table $\mathbf{2}$ List of Fama-French factors

\begin{tabular}{ll}
\hline Variable & Explanation \\
\hline RMRF & The excess return of the market portfolio \\
SMB & $\begin{array}{l}\text { The average returns on the small stock portfolios minus the average returns on the big stock } \\
\text { portfolios (Small Minus Big) }\end{array}$ \\
HML & The average returns on the high book-to-market ratio portfolios minus the average returns \\
& on the low book-to-market portfolios (High Minus Low) \\
RMW & The average returns on the robust operating profitability portfolios minus the average returns \\
& on the weak operating profitability portfolios (Robust Minus Weak) \\
CMA & The average returns on the conservative investment portfolios minus the average returns on \\
& the aggressive investment portfolios (Conservative Minus Aggressive)
\end{tabular}


and French, 2015). We then add the FinTech variable to see whether it has an effect on the stock price above and beyond these three- or five-factor models. The resulting regression equation is:

$$
\begin{aligned}
R_{i, t}-R_{f, t}= & a_{i}+\beta_{i} R M R F t+s_{i} S_{M B}+h_{t} H M L_{t}+r_{i} R M W_{t} \\
& +c_{i} \text { CMA }_{t}+\gamma_{i} \text { FinTech }_{t}+\varepsilon_{i, t},
\end{aligned}
$$

where RMRF is the excess return of the equity market relative to the risk-free rate, SMB is the return of small minus large capitalization stocks, HML is the return of high minus low book-to-market stocks, RMW is the return of robust minus weak profitability stocks, and CMA is the return of conservative minus aggressive investing stocks. The three-factor model does not include the RMW and CMA factors. Depending on our model, FinTecht represents the standardized FinTech funding volume and the funding volume growth rate, or the number of FinTech deals and the growth in the number of deals.

Since we have a panel data structure, we must determine how to model each parameter. We consider three model specifications: (a) pooled, (b) fixed effects, and (c) free. In the pooled model, we assume that each estimated coefficient is the same for each bank. In the fixed effects model, we assume bank-specific alphas, but keep the other parameters the same for each bank. In the free model, each parameter is bank-specific, except for the FinTech coefficient. We test the -coefficient for statistical significance for each model specification. In addition, we also include the results of a single regression equation on the banking industry returns, in which we do not use information at the individual bank level.

In the Appendix, we also report the results of a Seemingly Unrelated Regression specification, in which we also allow a bank-specific parameter $\gamma$. By studying the $\gamma$ coefficients on an individual level, we can analyze which banks seemed to be more affected by FinTech.

\section{Results}

We start this section with the analysis of the impact of the dollar-volume of FinTech funding on incumbent banks' stock returns. We then test the number of deals instead of the dollar-volume. Both measures could be relevant to measure the importance of FinTech in the US retail banking market. Table 3 contains our regression results.

First, we see that the parameter estimates for the three panel data models and the industry-level regression leads to similar parameter estimates. The three panel data models have higher associated $\mathrm{t}$-values than at the industry-level. This is due to the cross-sectional information used in the panel data setup, while at the industry-level we have only time-series variation.

Based on the panel data models, we see that the funding volume itself is not statistically significant, with $\mathrm{t}$-statistics ranging from 0.03 to 0.98 , depending on the panel data model and whether we use the three- or five-factor model as a benchmark. The number of deals is marginally significant, with t-statistics varying between 1.86 and 2.00 for the different panel data models. The results for the growth rates are much stronger; the t-statistics for the panel data models are well above 2.5 for each, indicating statistical significance. Since the coefficients are all positive, this implies that stock returns of incumbent retail banks are higher in periods with increasing FinTech funding or number 
Table 3 Empirical results

\begin{tabular}{|c|c|c|c|c|c|c|c|c|c|}
\hline \multirow{2}{*}{ Full sample } & & \multicolumn{2}{|c|}{ Funding volume } & \multicolumn{2}{|c|}{ Growth volume } & \multicolumn{2}{|c|}{ Number of deals } & \multicolumn{2}{|c|}{ Growth deals } \\
\hline & & 3 factor & 5 factor & 3 factor & 5 factor & 3 factor & 5 factor & 3 factor & 5 factor \\
\hline \multirow[t]{2}{*}{ Pooled } & Estimate & 0.08 & 0.00 & 0.11 & 0.12 & 0.18 & 0.18 & 0.35 & 0.39 \\
\hline & T-value & 0.82 & 0.03 & 2.64 & 2.87 & 1.90 & 1.89 & 3.00 & 3.29 \\
\hline \multirow[t]{2}{*}{ Fixed effects } & Estimate & 0.08 & 0.00 & 0.12 & 0.13 & 0.18 & 0.18 & 0.36 & 0.39 \\
\hline & T-value & 0.80 & 0.04 & 2.70 & 2.92 & 1.86 & 1.86 & 3.03 & 3.31 \\
\hline \multirow[t]{2}{*}{ Free } & Estimate & 0.09 & 0.01 & 0.12 & 0.13 & 0.18 & 0.19 & 0.37 & 0.39 \\
\hline & T-value & 0.98 & 0.07 & 3.04 & 3.24 & 2.00 & 2.08 & 3.35 & 3.56 \\
\hline \multirow[t]{2}{*}{ Industry } & Estimate & 0.08 & 0.01 & 0.12 & 0.13 & 0.19 & 0.19 & 0.36 & 0.40 \\
\hline & T-value & 0.31 & 0.02 & 1.02 & 1.13 & 0.72 & 0.74 & 1.15 & 1.29 \\
\hline
\end{tabular}

of deals. Hence, we do not find evidence of creative destruction, but rather that the FinTech industry has a positive spill-over to the traditional retail banking industry.

We show the results of the Seemingly Unrelated Regressions for the growth in FinTech funding in the Appendix in Table 5. These bank-specific estimates of the gamma parameter show that the positive coefficient above is an average across banks and that 16 of 47 banks have negative estimates, although none are statistically significant. Our results are not statistically significant for the level of funding, have different signs across banks, and are not statistically significant at the industry-level, suggesting that our finding of complementarity is fragile.

\section{Discussion and conclusion}

This paper aims to provide a new perspective on the debate about the impact of US digital banking start-ups on the performance of US retail banks by using quantitative analysis. Based on our empirical results, we reject both null hypotheses incorporating the effect of the growth of the volume of funding and the change in the number of deals, as all coefficients from our panel data models are positive and statistically significant. Therefore, we conclude that although the large sum of investments raised public awareness, the funding of digital banking start-ups is more likely to have a positive effect on the incumbents' stock returns than a negative effect. This suggests complementarity between FinTech and traditional banking, rather than substitution and disruptive innovation. However, our results are weaker for the level of funding, or if we investigate the banking industry returns.

Although we find positive and statistically significant results, we cannot rule out that our findings are spurious and alternative scenarios are also at play. First, while the FinTech start-ups are growing rapidly, they may still be too small to affect incumbent US retail banks. Within a period of less than five years, it is difficult for consumers to adapt to the new changes newcomers brought or to trust in their online and automatic services. Additionally, retail banks benefit from their ingrained advantages, such as their ability to create credit instantly. Second, the substitute and complementary effects may partly offset each other. On the one hand, successful FinTech firms may have weakened the banks' dominant position by improving the quality and efficiency of traditional services; on the other hand, banks have taken actions to respond to these challenges, possibly by acquiring FinTech start-ups or setting up their own FinTech affiliates. Third, FinTechs 
could have established a new channel to distribute financial services, as start-ups and incumbents might have different customer bases. If this is the case, direct competition may remain low, which makes it difficult to observe a clear relationship.

This study has several limitations. First, we used FinTech funding as a proxy for the potential value of the FinTech start-ups because no other data are available. Although we believe that we made reasonable assumptions, we cannot avoid the potentially negative impact of this proxy on the empirical analyses. It would also be interesting to investigate the effect on bank risk taking or competition within the industry, but we lack the necessary data for such a study. Second, the sample might be too small to draw conclusions for the time-series regressions due to the sample period of January 2010 until March 2016, which is rather short. However, these are the only data available. We also could not examine the geographical areas in which FinTech firms and traditional retail banks operate in more detail. Having data available in this area could lead to stronger claims on the causality between FinTech flows and retail bank performance. Similarly, we searched for information to differentiate the reaction of incumbent banks to FinTech developments. Whether banks ignore FinTech, fund their own start-ups, or cooperate with external FinTech firms should affect their stock prices. However, we could not find enough information on the incumbent banks to analyze, such a differentiated view. Another limitation might be that we use monthly data. Since technological innovations follow investments in FinTech firms, there may be a delayed reaction at the moment of the discovery of the innovation rather than at its initial financing. Here, we had to compromise between the frequency of our analysis and the length or our sample period. Using a quarterly frequency would decrease the number of observations and thus limit statistical inference, by definition. Third, as we discussed in the theoretical framework section, the Fama-French three-factor model suffers from shortcomings; for example, it ignores the momentum effect. Although the Fama-French model was improved by introducing two extra factors to create the five-factor model, the momentum effect and the low volatility factor are still of concern (Blitz et al., 2016).

Future research could undertake an extended cross-sectional analysis of the effect of start-ups by studying different countries, because other countries may have a different structure in the retail banking industry and impact outside the US. It would also be worthwhile to expand our sample of listed banks to include non-listed banks, although these studies would have to measure performance through low frequency accounting measures instead. Moreover, examining the effect of different investment stages on the incumbents' stock returns might provide more insight in the fast-growing FinTech industry.

\section{Endnotes}

${ }^{1}$ Quotes from the following blog post: http://blog.levelmoney.com/post/ 107894276051/the-next-level

${ }^{2}$ Davis, Fama, and French (2000) form six value-weighted portfolios, S/L, S/M, S/H, $\mathrm{B} / \mathrm{L}, \mathrm{B} / \mathrm{M}$, and $\mathrm{B} / \mathrm{H}$, as intersections of the size and book-to-market equity $(\mathrm{B} / \mathrm{M})$ groups. For example, S/L is the value-weighted return on the portfolio of stocks below the NYSE median in size and in the bottom $30 \%$ of $\mathrm{B} / \mathrm{M}$.

${ }^{3}$ See https://www.cbinsights.com/blog/private-company-financing-data-sourcescruncher/ for more information on the data collection process employed by $\mathrm{CB}$ Insights. 
${ }^{4}$ Funding data obtained from CB Insights includes all types of financing available, such as venture capital, angel funding, IPOs, and private equity investments.

${ }^{5}$ See Deloitte, "The evolving Fintech regulatory environment," https://www2.deloitte.com/us/en/pages/regulatory/articles/fintech-risk-management.html

${ }^{6}$ See Reuters, "Fintech challenges for regulators: Evolution or revolution," http:// www.reuters.com/article/bcfinreg-fintech-regulation/fintech-challenge-for-regulatorsevolution-or-revolution-idUSKBN17N1SI

${ }^{7}$ http://www.credio.com

${ }^{8}$ For comparison, we adjust the S\&P Composite 1500 Financials (Sector) Total Return to start from the same level as the S\&P US Composite 1500 Index Total Return.

${ }^{9}$ http://mba.tuck.dartmouth.edu/pages/faculty/ken.french/data_library.html

\section{Appendix}

Table 4 Raw data on FinTech funding and number of deals

\begin{tabular}{|c|c|c|c|c|c|c|c|c|c|c|c|c|c|c|}
\hline \multicolumn{15}{|c|}{ Panel A: Entire sample } \\
\hline & \multicolumn{2}{|l|}{2010} & \multicolumn{2}{|l|}{2011} & \multicolumn{2}{|l|}{2012} & \multicolumn{2}{|l|}{2013} & \multicolumn{2}{|l|}{2014} & \multicolumn{2}{|l|}{2015} & \multicolumn{2}{|l|}{2016} \\
\hline & Fund & Deal & Fund & Deal & Fund & Deal & Fund & Deal & Fund & Deal & Fund & Deal & Fund & Deal \\
\hline January & 26.6 & 6 & 27.0 & 8 & 106.8 & 7 & 72.7 & 17 & 22.2 & 9 & 91.5 & 12 & 174.1 & 22 \\
\hline February & 2.3 & 2 & 18.2 & 6 & 1.2 & 1 & 84.5 & 9 & 116.0 & 16 & 148.2 & 16 & 73.8 & 16 \\
\hline March & 270.7 & 7 & 44.9 & 11 & 19.9 & 3 & 29.2 & 7 & 250.0 & 16 & 184.8 & 13 & 245.3 & 20 \\
\hline April & 57.6 & 8 & 1.6 & 2 & 17.5 & 9 & 340.2 & 5 & 520.6 & 21 & 1353.8 & 17 & & \\
\hline May & 5.3 & 4 & 69.4 & 12 & 27.2 & 4 & 184.8 & 12 & 141.9 & 6 & 358.2 & 20 & & \\
\hline June & 40.8 & 5 & 118.8 & 11 & 54.5 & 8 & 81.5 & 8 & 3575.2 & 10 & 363.3 & 13 & & \\
\hline July & 264.1 & 9 & 44.3 & 4 & 22.4 & 4 & 96.7 & 18 & 693.6 & 21 & 525.8 & 22 & & \\
\hline August & 0.5 & 2 & 82.2 & 10 & 141.2 & 10 & 44.5 & 11 & 237.0 & 6 & 467.2 & 8 & & \\
\hline September & 147.9 & 10 & 107.0 & 10 & 73.3 & 7 & 250.2 & 12 & 109.7 & 9 & 547.4 & 22 & & \\
\hline October & 232.8 & 4 & 30.5 & 2 & 57.1 & 7 & 371.7 & 11 & 126.7 & 19 & 3905.9 & 25 & & \\
\hline November & 29.9 & 6 & 0.0 & 1 & 2.9 & 2 & 79.0 & 8 & 142.6 & 10 & 355.2 & 14 & & \\
\hline December & 347.9 & 9 & 20.2 & 6 & 55.5 & 6 & 24.2 & 7 & 1989.1 & 19 & 33.6 & 10 & & \\
\hline \multicolumn{15}{|c|}{ Panel B: Subsample with only "Consumer FinTech" } \\
\hline & 2010 & & 2011 & & 2012 & & 2013 & & 2014 & & 2015 & & 2016 & \\
\hline & Fund & Deal & Fund & Deal & Fund & Deal & Fund & Deal & Fund & Deal & Fund & Deal & Fund & Deal \\
\hline January & 0.0 & 0 & 0.0 & 0 & 20.4 & 2 & 33.6 & 5 & 12.2 & 1 & 24.1 & 5 & 68.7 & 8 \\
\hline February & 2.0 & 1 & 4.5 & 2 & 0.0 & 0 & 3.1 & 2 & 20.3 & 4 & 104.6 & 5 & 16.4 & 4 \\
\hline March & 6.9 & 2 & 6.2 & 1 & 0.0 & 0 & 5.0 & 1 & 90.4 & 3 & 0.7 & 1 & 38.2 & 5 \\
\hline April & 45.4 & 4 & 0.0 & 0 & 0.0 & 1 & 30.0 & 1 & 147.3 & 5 & 263.6 & 7 & & \\
\hline May & 0.0 & 0 & 15.7 & 2 & 0.1 & 1 & 162.0 & 6 & 91.8 & 4 & 209.4 & 11 & & \\
\hline June & 38.0 & 2 & 31.2 & 2 & 29.5 & 3 & 40.1 & 3 & 3.1 & 3 & 183.8 & 4 & & \\
\hline July & 0.0 & 0 & 5.0 & 1 & 20.8 & 1 & 18.6 & 4 & 671.0 & 12 & 266.7 & 4 & & \\
\hline August & 0.0 & 0 & 50.0 & 3 & 4.5 & 4 & 25.1 & 4 & 206.5 & 2 & 409.1 & 4 & & \\
\hline September & 2.9 & 1 & 29.0 & 2 & 0.0 & 0 & 95.9 & 4 & 81.1 & 3 & 376.7 & 11 & & \\
\hline October & 1.3 & 2 & 30.0 & 1 & 1.5 & 1 & 17.7 & 6 & 69.7 & 5 & 237.3 & 10 & & \\
\hline November & 16.0 & 1 & 0.0 & 0 & 0.0 & 0 & 57.0 & 1 & 2.5 & 1 & 331.3 & 9 & & \\
\hline December & 0.0 & 0 & 0.0 & 0 & 1.9 & 2 & 7.0 & 1 & 1411.2 & 9 & 18.4 & 3 & & \\
\hline
\end{tabular}


Table 5 OLS Regression Results of Models with FinTech Volume Growth

\begin{tabular}{|c|c|c|c|c|c|c|c|c|c|c|}
\hline Ticker & Name & alpha & & RMRF & & SMB & & $\mathrm{HML}$ & & $\overline{\text { FINTECH }}$ \\
\hline- & Entire banking industry & -0.10 & & 0.90 & * & 0.61 & * & 0.46 & & 0.12 \\
\hline BAC & Bank of America Corp & -1.03 & & 1.36 & * & 0.48 & & 0.81 & & 0.45 \\
\hline BBT & BB\&T Corp & -0.41 & & 0.94 & * & 0.50 & & 0.23 & & 0.21 \\
\hline BK & Bank of New York Mellon Corp & -0.61 & & 1.27 & * & -0.09 & & 0.75 & & 0.09 \\
\hline BOKF & BOK Financial Corp & -0.16 & & 0.72 & * & 0.61 & * & 0.50 & & 0.11 \\
\hline BXS & BancorpSouth Inc & -0.50 & & 0.89 & * & 1.07 & * & 0.69 & * & 0.70 \\
\hline C & Citigroup Inc & -1.10 & & 1.70 & * & 0.09 & & 0.60 & & 0.08 \\
\hline CARE & Carter Bank \& Trust & 1.12 & & 0.27 & & 0.37 & & 0.35 & & -0.22 \\
\hline CBF & Capital Bank Financial Corp & 1.27 & & 0.20 & & 0.66 & & -0.34 & & 0.79 \\
\hline CFG & Citizens Financial Group Inc & -0.39 & & 1.32 & * & 0.54 & & 0.48 & & -1.23 \\
\hline CMA & Comerica Inc & -0.70 & & 1.17 & * & 0.61 & * & 0.78 & & -0.03 \\
\hline COF & Capital One Financial Corp & 0.00 & & 1.11 & * & 0.27 & & 0.57 & & -0.14 \\
\hline EWBC & East West Bancorp Inc & -0.12 & & 1.31 & * & 1.00 & * & 0.14 & & -0.33 \\
\hline FFIN & First Financial Bankshares Inc & 0.14 & & 0.91 & * & 1.15 & * & 0.31 & & -0.22 \\
\hline FITB & Fifth Third Bancorp & -0.46 & & 1.21 & * & 0.41 & & 0.44 & & 0.28 \\
\hline FRC & First Republic Bank/CA & 0.69 & & 1.00 & * & 0.48 & & 0.12 & & 0.43 \\
\hline HSBC & HSBC Holdings PLC & -1.38 & * & 1.15 & * & -0.50 & & 0.22 & & -0.26 \\
\hline IBKC & IBERIABANK Corp & -0.38 & & 0.76 & * & 1.05 & * & 0.74 & & 0.15 \\
\hline IBTX & Independent Bank Group Inc & -0.31 & & 1.16 & * & 1.54 & * & 0.20 & & 0.81 \\
\hline JPM & JPMorgan Chase \& Co & 0.37 & & -1.42 & * & 0.06 & & -0.60 & & -0.31 \\
\hline MTB & M\&T Bank Corp & 0.34 & & 0.59 & * & 0.26 & & 0.52 & & -0.05 \\
\hline NTRS & Northern Trust Corp & -0.58 & & 1.00 & * & 0.19 & & 0.31 & & -0.07 \\
\hline NWBI & Northwest Bancshares Inc & 0.27 & & 0.46 & * & 0.38 & & 0.48 & & 0.18 \\
\hline OZRK & Bank of the Ozarks Inc & 1.75 & * & 0.96 & * & 0.84 & * & 0.34 & & -0.11 \\
\hline PB & Prosperity Bancshares Inc & -0.51 & & 1.03 & * & 1.12 & * & 0.35 & & 0.05 \\
\hline РBCT & People's United Financial Inc & -0.31 & & 0.72 & * & 0.28 & & 0.22 & & 0.02 \\
\hline PNBI & Pioneer Bankshares Inc & 0.78 & & 0.26 & & -0.01 & & 0.40 & & -0.01 \\
\hline PNC & PNC Financial Services Group Inc & 0.01 & & 0.81 & * & 0.52 & & 0.32 & & 0.33 \\
\hline PRK & Park National Corp & 0.65 & & 0.55 & * & 1.13 & * & 0.17 & & 0.33 \\
\hline SNV & Synovus Financial Corp & -0.78 & & 1.81 & * & 0.70 & * & 0.28 & & -0.17 \\
\hline STI & SunTrust Banks Inc & -0.56 & & 1.38 & * & 0.41 & & 0.50 & & 0.33 \\
\hline SUSQ & Susquehanna Bancshares Inc & -0.52 & & 1.57 & * & 0.35 & & 0.26 & & -0.16 \\
\hline SYBJF & Security Bank Corp & 3.83 & * & 0.06 & & 1.64 & * & 1.03 & & 0.04 \\
\hline TCB & TCF Financial Corp & -0.84 & & 0.94 & * & 0.82 & * & 0.60 & & 0.11 \\
\hline TD & Toronto-Dominion Bank & 0.00 & & 0.93 & * & -0.17 & & 0.62 & & 0.44 \\
\hline TRMK & Trustmark Corp & -1.09 & & 1.15 & * & 0.30 & & 0.23 & & 0.50 \\
\hline TRST & TrustCo Bank Corp NY & -0.06 & & 0.67 & * & 1.05 & * & 0.76 & & 0.01 \\
\hline UBSH & Union Bankshares Corp & 0.24 & & 1.06 & * & 0.82 & * & 0.37 & & 0.29 \\
\hline UCBI & United Community Banks Inc./GA & 0.39 & & 0.34 & * & 1.71 & * & 1.36 & & 0.32 \\
\hline UMBF & UMB Financial Corp & -0.07 & & 0.75 & * & 1.16 & * & 0.26 & & 0.43 \\
\hline UMPQ & Umpqua Holdings Corp & -0.26 & & 1.08 & * & 1.38 & * & 0.55 & & -0.11 \\
\hline USB & US Bancorp & 0.01 & & 0.83 & * & 0.06 & & 0.11 & & 0.27 \\
\hline VLY & Valley National Bancorp & -0.47 & & 0.75 & * & 0.77 & * & 0.50 & & 0.07 \\
\hline WAFD & Washington Federal Inc & -0.35 & & 0.94 & * & 0.70 & * & 0.64 & * & 0.63 \\
\hline
\end{tabular}


Table 5 OLS Regression Results of Models with FinTech Volume Growth (Continued)

\begin{tabular}{|c|c|c|c|c|c|c|c|c|}
\hline Ticker & Name & alpha & RMRF & & SMB & & $\mathrm{HML}$ & FINTECH \\
\hline WBS & Webster Financial Corp & 0.23 & 1.25 & $*$ & 0.91 & * & 0.45 & -0.28 \\
\hline WFC & Wells Fargo \& Co & 0.02 & 0.97 & * & 0.05 & & 0.44 & 0.41 \\
\hline WSBC & WesBanco Inc & 0.85 & 0.61 & * & 1.21 & * & 0.94 & 0.18 \\
\hline \multirow[t]{4}{*}{$\mathrm{ZION}$} & Zions Bancorporation & -0.70 & 1.47 & * & 1.04 & $*$ & 1.13 & 0.28 \\
\hline & average & -0.04 & 0.89 & & 0.64 & & 0.45 & 0.12 \\
\hline & negative & 29 & 1 & & 4 & & 2 & 16 \\
\hline & positive & 18 & 46 & & 43 & & 45 & 31 \\
\hline
\end{tabular}

A after a coefficient * denotes statistical significance at the $5 \%$ level

\section{Acknowledgements}

We would like to acknowledge the valuable comments and suggestions from four anonymous reviewers and discussions with the Erasmus School of Economics Bachelor Honours Class that helped us to improve the manuscript.

\section{Availability of data and materials}

We have described our data sources in detail in the main text, but are not allowed to redistribute these ourselves.

\section{Authors' contributions}

$Y L$ and RS jointly carried out the first phase of the research design, the literature survey, the data collection, the statistical analyses, and first draft of the manuscript. LS participated in the research design, interpretation of empirical results, and helped draft the manuscript. LS, YL, and RS worked together the past couple of weeks to address all the comments made by the reviewers. All authors read and approved the final manuscript.

\section{Funding}

We received no funding for this project.

\section{Competing interests}

The authors declare that they have no competing interests. LS would like to convey that he is also affiliated with Robeco Institutional Asset Management, an investment company based in the Netherlands. This research was done purely using his academic title, and LS sees no competing interests between the manuscript and this additional affiliation.

\section{Publisher's Note}

Springer Nature remains neutral with regard to jurisdictional claims in published maps and institutional affiliations.

\section{Received: 5 August 2016 Accepted: 25 October 2017}

Published online: 09 November 2017

\section{References}

Aaker D, Keller K (1990) Consumer Evaluations of Brand Extensions. Journal of Marketing:27-41

Afuah A, Utterback J (1997) Responding to Structural Industry Changes: A Technological Evolution Perspective. Industrial and Corporate Change:183-202

Benner M (2007) The incumbent discount: Stock market categories and response to radical technological change. Academy of Management Review:703-720

Blitz, D., Hanauer, M., \& van Vliet, P. (2016). Five conerns with the five-factor model. Retrieved from https://ssrn.com/ abstract $=2862317$

Buchack, G., Matvos, G., Piskorski, T., and Seru, A., 2017. Fintech, regulatory arbitrage, and the rise of shadow banks. NBER Working Paper 23288.

Cannon S, Summers L (2014, October 13) How Uber and the Sharing Economy Can Win Over Regulators, Harvard Business Review

Chishti S, Barberis J (2016) The FinTech Book. Wiley, New York

Christensen C (1997) The innovator's dilemma: when new technologies cause great firms to fail. Harvard Business Review Press, Boston

Davila A, Foster G, Gupta M (2003) Venture capital financing and the growth of startup firms. Journal of Business Venturing:689-708

Davis JL, Fama EF, French KR (2000) Characteristics, Covariances, and Average Returns: 1929 to 1997. The Journal of Finance:389-406

Dean B, Giglierano J (1990) Multistage financing of technical start-up companies in silicon valley. Journal of Business Venturing:375-389

Demos, T. (2016, April 20). Loans for Weddings: Fintech Learns to Focus. The Wall Street Journal.

Dickerson J, Masood S, Skan J (2015) The Future of Fintech and Banking: Digitally disrupted or reimagined? Accenture, London 
Dunkley, E. (2015, December 8). Lending services revolution piles pressure on banks as fintech sector grows. Retrieved March 6, 2016, from Financial Times: http://www.ft.com/int//cms/s/0/653d64b2-77ce-11e5-a95a-27d368e1ddf7. html\#axzz41waAnOyv

Ernst, Young (2014) Landscaping UK Fintech. Ernst and Young LLP, London

Fama EF, French KR (1993) Common risk factors in the returns on stocks and bonds. Journal of Financial Economics:3-56

Fama EF, French KR (2004) The Capital Asset Pricing Model: Theory and Evidence. The Journal of Economic Perspectives: $25-46$

Fama EF, French KR (2015) A five-factor asset pricing model. Journal of Financial Economics:1-22

Ferrari R (2016) FinTech Impact on Retail Banking - From a Universal Banking Model to Banking Verticalization. In: Chishti S, Barberis J (eds) The FinTech Book: The Financial Technology Handbook for Investors, Entrepreneurs and Visionaries. Wiley, London, pp 248-252

Frank R (2009) Microeconomics and Behavior. McGraw-Hill Education, Boston

Goh, K., \& Kauffman, R. (2013). Firm strategy and the Internet in U.S. commercial banking. Journal of Management Information Systems, 9-40.

Hannan TH, McDowell JM (1984) The Determinants of Technology Adoption: The Case of the Banking Firm. The RAND Journal of Economics:328-335

Hayashi Y (2016, April 7) Consumer Watchdog Chief Sees Role for Fintech in Payday Lending. The Wallstreet Journal

Huang, D. (2015, November 18). Banks and Fintech Firms' Relationship Status: It's Complicated. Retrieved March 5, 2016, from Wall Street Journal: http://www.wsj.com/articles/banks-and-fintech-firms-relationship-status-its-complicated1447842603

Jegadeesh N, Titman S (1993) Returns to Buying Winners and Selling Losers: Implications for Stock Market Efficiency. The Journal of Finance:65-91

Juengerkes BE (2016) FinTechs and Banks - Collaboration is Key. In: Chishti S, Barberis J (eds) The FinTech Book: The Financial Technology Handbook for Investors, Entrepreneurs and Visionaries. Wiley, London, pp 179-182

Jun J, Yeo E (2016) Entry of FinTech Firms and Competition in the Retail Payments Market. Asia-Pacific Journal of Financial Studies:159-184

Kauffman, R., Liu, J., \& Ma, D. (2015). Competition, Cooperation and Regulation: Understanding the Evolution of the Mobile Payments Technology Ecosystem. Electronic Commerce Research and Applications, 372-391.

Kaul A (2012) Technology and Corporate Scope: Firm and Rival Innovation as Antecedents of Corporate Transactions. Strategic Management Journal:347-367

KPMG (2016) The Pulse of Fintech, 2015 in Review. KPMG, London

Laven M, Bruggink D (2016) How FinTech is transforming the way money moves around the world: An interview with Mike Laven. Journal of Payments Strategy \& Systems:6-12

Lin Z, Whinston A, Fan S (2015) Harnessing Internet finance with innovative cyber credit management. Financial Innovation 1(5)

Liu, K., \& Miller, D. (2014). Creative Destruction: Evidence From Initial Public Offerings. Academy of Management Proceedings.

Mina A, Lahr H, Hughes A (2013) The demand and supply of external finance for innovative firms. Industrial and Corporate Change:869-901

Peters, G. W., \& Panayi, E. (2015, November 18). Understanding Modern Banking Ledgers Through Blockchain Technologies: Future of Transaction Processing and Smart Contracts on the Internet of Money. Retrieved from Social Science Research Network: http://papers.ssrn.com/sol3/papers.cfm?abstract_id=2692487

PwC (2016) Blurred lines: How FinTech is shaping Financial Services. PwC, London

Sharpe WF (1964) Capital asset prices: a theory of market equilibrium under conditions of risk. The Journal of Finance: $425-442$

Sood A, Tellis G (2009) Do Innovations Really Pay Off? Total Stock Market Returns to Innovation. Marketing Science:442-456

Sorkin, A. (2016, April 6). Fintech Firms Are Taking On the Big Banks, but Can They Win? The New York Times.

The Economist. (2015a, May 9). The Fintech Revolution. The Economist.

The Economist. (2015b, June 16). Why fintech won't kill banks. The Economist.

Wang H, Chen K, Zhu W, Song Z (2015a) A process model on P2P lending. Financial Innovation 1(3)

Wang P, Zheng H, Chen D, Ding L (2015b) Exploring the critical factors influencing online lending intentions. Financial Innovation 1(8)

Wood G, Buchanen A (2015) Advancing Egalitarianism. In: Lee Kuo D (ed) Chuen, Handbook of Digital Currency: Bitcoin, Innovation, Financial Instruments, and Big Data. Elsevier, London, pp 385-401

Yan J, Yu W, Zhao J (2015) How signaling and search costs affect information asymmetry in P2P lending: the economics of big data. Financial Innovation 1(19) 